\title{
INDEX TO VOLUME XI
}

\section{A}

-a medial and final in Gāndhārī, 789-791.

$\check{a}$ of Sanskrit in Sinhalese, 824-9.

$\tilde{a}$ - initial in Dravidian, 595-616.

A propos de l'auteur de la recension Bradley de la Grande Chronique d'Ayuthia (J. Burhay), 144-7.

Abrotr (Nabia), Aishah the Beloved of Mohammed, 221 .

Abdullah (S. M.), a Descriptive Catalogue of Persian, Urdu, and Arabic Manuscripts in the Panjab University Library, $662 \mathrm{f}$.

Abraham (R. C.), The Tiv People, 905 f.

L'Agnihotra (P.-E. Dumont), $226 \mathrm{f}$.

Aysartan, king, 557, 559-563, 578.

Ahl-i Haqq, 76, $88 \mathrm{f}$., $94 \mathrm{f}$.

A hmad b. at-Tayyib as-Sarahsi (F. Rosenthal), $435,437$.

Ahmad Khān Kōmāsĩ, 96-103.

a $i$ of Sanskrit in "Sinhalese, $834 \mathrm{f}$.

Aishah, the Beloved of Mohammed (Nabia Abbott), 221.

Akabarasahi - sringaradarpana (Padmasundara), 884, $886 \mathrm{f}$.

Akhsatān b. Minuchihr, king, 557, 559-563, 578.

'Alī ibn al-'Abbās Ibn al-Rūmī, 874.

ALI Riza Bey, obituary of, 912.

Amgoka, king, $522 \mathrm{f}$.

$a m i n, 454 \mathrm{ff}$.

$\bar{a} m \bar{o} n, 455 \mathrm{f}$.

Anacreon, text of two poems of, revised by Sir W. Jones, 669-672.

Ānandacandra, king, 359, 365 f., 373, 377-9, $381 \mathrm{f} ., 383$.

Ancient Hebrew Marriage Laws (E. Neufeld), 872-3.

Ancient Vijñaptipatras (Hirananda Sastri), 227-9.

al-Andalus, 435, 438.

Andronicus Comnenus, 550, $554 \mathrm{ff}$.

Ansāb al-Ashräf (al-Balādhurī), vol. 4 в, $221 \mathrm{f}$.

Antonius, Parthian expedition of, 243, 258263.

Arabic, Sir W. Jones' studies in, 695-8.

Arakan, early coins of, $357 \mathrm{f}$., 383-5.

Arakan, Some Sanskrit Inseriptions of $(\dagger \mathrm{E}$. H. Johnston), 357-385.

ARberry (A. J.), Modern Persian Reader, 883; New Light on Sir William Jones, 673-685 ; Orient Pearls at Random Strung, 699-712.

Ardashīr, chronology of, $7 \mathrm{ff}$.

Armajani (YaHYa), and Moghadam (M. E.), Descriptive Catalog of the Garrett Collection of . . Manuscripts, $224 \mathrm{f}$.

Arya, in personal names, 140-3.

AsañaA, La Somme du Grand Véhicule, $446 \mathrm{f}$.

Assamese: its Formation and Development (Banikanta Kakati), $889 \mathrm{f}$.

AtkIns (S. D.), Pussan in the Rig-Veda, 226.
Atropatene, Roman and Byzantine Campaigns in (V. Minorsky), 243-265.

$\breve{a} u$ of Sanskrit in Sinhalese, $834 \mathrm{f}$.

acasama, $541 \mathrm{ff}$.

Aya, Ayya, 140-3.

B

Бабидские Восстания в Иране, (М. S. Ivanov), 875, 878-880.

Bayiatavov öpos, $473 \mathrm{f}$.

Bahrām Chūbīn, 244 f., 264.

BAILEY (H. W.), Gāndhārī, 764-797; Iranica, I-5; The Khotan Dharmapada, 488-512;

A Turkish-Khotanese Vocabulary, 290-6.

AL-BALĀDHURī, Ansāb al-Ashrāf, vol. $4 \mathrm{~B}, 221 \mathrm{f}$. bana-, 765-7.

Barlaam and Yoasaf, 487.

Barmak, 2.

BarnetT (L. D.), Note on an Early Indian Coin, 140-3 ; rev., 227-9, 445-8; rev. (jointly), 232-5.

BarnetT (R. D.), rev., $220 \mathrm{f}$.

Baroda State Museum and Picture Gallery, Bulletin of, $887 \mathrm{f}$.

beryl, 304-6.

Bhadrakalpikä-sütra, 775-8.

Bhagavad Gita. Translated and interpreted by Franklin Edgerton, $884 \mathrm{f}$.

Bhaiṣajyaguruvaiḍ̄uryaprabhatathāgatasūtra, 731 ff.

Bhoti, $539 \mathrm{ff}$.

Black Byzantium, $A$ (S. F. Nadel), $905 \mathrm{f}$.

body, terms for parts of the, in Dravidian and Uralian, 328-356.

Book of the Giants, The (W. B. Henning), 52-74.

Bradley (D. B.), his recension of the Chronicle of Ayuthia, 144-7.

bramma, 787-9.

Brovgh (JoHN), Sattayā, $308 \mathrm{f}$.

Brown (W. Norman), A Pillared Hall from a Temple at Madura, $227 \mathrm{f}$.

Bulletin of the Baroda State Museum and Picture Gallery, $887 \mathrm{f}$.

Bumni(m), $539 \mathrm{ff}$.

Burnay (J.), À propos de l'auteur de la recension Bradley de la Grande Chronique d'Ayuthia, 144-7.

Biknow (T.), Dravidian Studies III, 122139 ; IV, 328-356 ; V, 595-616 ; rev., $230 \mathrm{f}$.

C

Caḍ́ota, 522 f., 538.

Cresar and the Thieves, tale of the, 477-480.

Candra dynasty of Arakan, 367-373, 375-385.

Catalogue of the Sanskrit Manuscripts in the Panjab University Library, Vol. II, 446.

Čěčast, Lake, 263-5.

Chao (T. C.), and Smon (W.), Structure Drill in Chinese, $893,900 \mathrm{f}$.

China Among the Powers (D. N. Rowe), 893, 896-8. 
China, art of, 440-2.

China, Marvazi on, 232-5.

Chinese Philosophy in Classical Times (E. R. Hughes), 235-8.

Chinese Reader and Guide to Conversation (W. Simon and C. H. Lu), 893, 899.

Chinese Sentence Series (W. Simon and C. H. Lu), 893, 899.

"Christian Ode" of Khāqānī, 550-578.

Civil Service in India under the East India Company (A. K. Ghosal), 887-9.

Coins of early kings of Arakan, $357 \mathrm{f}$., 383-5.

Colloquial Hindustani (A. H. Harley), $439 \mathrm{f}$.

CoOMaraswamy (A. K.), Spiritual Authority and Temporal Power in the Indian Theory of Government, $438 \mathrm{f}$.

Crosby (K. H.), An Introduction to the Study of Mende, $665 \mathrm{f}$.

crystal, 297-304, $306 \mathrm{f}$.

Cyrenaica, Sanusiya Order in, 843-853.

1)

daēnā, $476 \mathrm{f}$.

Daniels (F. J.), rev., 90I-4.

Dated Chinese Manuscripts in the Stein Collection VI (L. Giles), 148-173.

David ben Abraham aL-F̄̄sī, Kitäb Jāmi al-Alfäz, $873 \mathrm{f}$.

Daylam, 762 .

Descriptive Catalog of the Garrelt Collection of .. Manuscripts (M. E. Moghadam and Y. Armajani), $224 \mathrm{f}$.

Descriptive Catalogue of Persian, Urdu, and Arabic Manuscripts in the Panjab University Library (S. M. Abdullah), 662 f.

Dessoulavy (C. L.), Gate of the East and Garden of Semitic Roots, $224 \mathrm{f}$.

Dharmapada, The Khotan, 488-512.

Dhavalaǵu Bahudhivá, 524.

Dīrghanakhasūtra, $730 \mathrm{f}$.

Documents Tigrigna (W. Leslau), 873-5.

Dravidian Element in Sinhalese, The (C. E. Godakumbura), 837-841.

Dravidian Studies (T. Burrow), III, 122-139 ; IV, 328-356 ; V, 595-616.

draysa-, $767 \mathrm{f}$.

dru- in Gāndhārī, 791.

Dumont (P.-E.), L'Agnihotra, $226 \mathrm{f}$.

Duncop (D. M.), The Karaits of Eastern Asia, 276-289.

symbynty, $479 \mathrm{f}$.

Dynamics of Clanship Among the Tallensi, The (M. Fortes), 906-8.

E

Early Sasanians, The (S. H. Taqizadeh), 6-51. Eastern Sudanic Languages, The (A. N. Tucker), $443 \mathrm{f}$.

Edakrton (FRankLIN), Bhagavad Gitā, Trans. lated and interpreted, etc., $884 \mathrm{f}$.

Endere, 521 ff.

erjhuna, 535.

Etching of a Tormented Age (Hsiao Ch'ien), $235,238 \mathrm{f}$

Evans-Pritchard (E. E.). See Pritchard (E. E. Evans-)

Everyday Hebrew (Ch. Rabin), 435, $437 \mathrm{f}$.
Fakhr al-Dīn As'ad Gurgāni, his Viss $u$ Rāmin, 741-763.

Farmer (H. G.), Sa'adyah Gaon on the Influence of Music, 435-7.

farn, 477.

Fatimids, Ismaili tradition on rise of the, 221-3.

Faylaquis, 574.

Fire-temple of Shī, 247-250, 253 n., 254-8, $264 \mathrm{f}$.

Fishes, tale of the three, 471.

FitzGarald (S. G. Vhesey-), Sir William Jones, the Jurist, 807-817 ; rev,, 872-3.

Foreign Sounds in Swahili (A. N. Tucker), 854-871.

Fortes (M.), The Dynamics of Clanship Among the Tallensi, 906-8.

Frzee (A. A. A.), A Shi ite Creed, 221, 223 f.

G

gandarawa, 482.

Gāndhārī (H. W. Bailey), 764-797.

Ganzak, $248 \mathrm{ff}$.

Garrett Collection of Manuscripts, Catalog of, $224 \mathrm{f}$.

Gate of the East and Garden of Semitic Roots (C. L. Dessoulavy), $224 \mathrm{f}$.

Ghosal (Akshoy Kumar), Civil Service in India under the East India Company, 887-9.

Giants, in Manichæan legend, 52-74.

Grues (LiOnel), Dated Chinese Manuscripts in the Stein Collection VI, 148-173; rev., 235-8, 893-901; (jointly), 232-5.

yntru., 482.

Goodrior (Chauncey), A Pocket Dictionary (Chinese-English) and Pekingese Syllabary, $893,898$.

Goodrich (L. Carrington), A Short History of the Chinese People, 893-5.

Gōōān, $77 \mathrm{ff}$.

Gordlevskx (V.), Государство Сельдакукидов Малой Азии, 875, 880-3.

Государство Сельджукидов Малой Азии, (V. Gordlevsky), 875, 880-3.

Gould (Sir Basil), and Richardson (H. E.), Tibetan Word Book, Tibetan Syllables, and Tibetan Sentences, $445 \mathrm{f}$.

Grammar of the Oldest Kanarese Inscriptions, $A$ (A. N. Narasimhia), $230 \mathrm{f}$.

Grammar of the Pokau Language (P. A. Lanyon-Orgill), 641-655.

Gray (Basic), rev., 440-2.

Greek Sources for the History of the Turks in the Sixth Century, On the (C. A. Macartney), 266-275.

Green (Margaret M.), rev., $905 \mathrm{f}$.

GUEST (RHOvoN), Life and Works of Ibn er $\operatorname{Ram} \hat{\imath}, 873 \mathrm{f}$.

gūina-, 765-7.

Gūrāb, 761 f.

Gūrān, The (V. Minorsky), 75-103.

Gurgāni (Fakhr al-Din As'ad), his Vìs $u$ Rā $m \bar{i} n, 741-763$.

$\gamma z \delta^{\prime} n-, 479$. 
$\mathrm{H}$

$h$ in Gāndhārī, 791-3.

Hāfiz, Sir W. Jones' translations of, 699-712.

Ḧamadān, 761-3.

Harding (L.), Wellcome-Marston Arehæological Expedition to the Near East. Lachish II, 656-9.

HaRLeY (A. H.), Colloquial Hindustani, 439 f. ; rev., $224 \mathrm{f} ., 662 \mathrm{f}$.

Henning (W. B.), The Book of the Giants, 52-74; note on Manichæan hymn, 216-19; Sogdian Tales, 465-487; The Sogdian Texts of Paris, 713-740.

Heraclius, Persian campaigns of, 243, $248 \mathrm{ff}$.

Hettlaratchi (D. E.), A Note on tuthāyatanāni, 579.

hinajha, $513 \mathrm{ff}$.

Hindu Conception of the Deity as culminating in Rãmānuja, The (Bh. Kumarappa), $229 \mathrm{f}$.

Hirananda Sastri, Ancient Vijñaptipatras, 227-9.

How to Study and Write Chinese Characters (W. Simon), 893, 900.

Hsiao Ch'inn, Etching of a Tormented Age, $235,238 \mathrm{f}$.

Huang (SIU-ChI), Lu Hsiang-shan, 893, $895 \mathrm{f}$.

Hughes (E. R.), Chinese Philosophy in Classical Times, 235-8.

Huraidha, inseription at, 451-464.

\section{I}

$\stackrel{*}{i}$ of Sanskrit in Sinhalese, 829-834.

Ibn al-Rūmì, 874.

Ibn al-Saqqā, $569,573$.

India, Marvazi on, 232-5.

Indo-Aryan and Dravidian (A. Master), 297307.

Indo-Aryan Language of South-India, An : Sauräşțra-bhāşã (H. N. Randle), 104-121, 310-327.

Influence of Sir William Jones upon Sanskrit Studies, The (A, Master), 798-806.

Inge (C. H.), Wellcome-Marston Archrological Expedition to the Near East. Lachish II, 656-9.

InNes (A. Rose-), Vocabulary of Common Japanese Words, 901-4.

Inscription from the Temple of Sin at Huraidha in the Hadhramawt, An (Sidney Smith), 451-464.

Introduction au Tamoul (P. Meile), $890 \mathrm{f}$.

Introduction to the Study of Mende, $A n$ (K. $\mathrm{H}$. Crosby), $665 \mathrm{f}$

Iran, Old Routes of Western (Sir M. A. Stein), 659-661.

Iranica (H. W. Bailey), 1-5.

Ismaili Tradition Concerning the Rise of the Fatimids (W. Ivanow), 221-3.

Italy and the Sanusiya Order in Cyrenaica (E. E. Evans-Pritchard), 843-853.

Ivanov (M. S.), Баб̆идские Босстания в Иране, 875, 878-880.

IVANOW (W.), Ismaili Tradition concerning the Rise of the Fatimids, 221-3.

\section{J}

Jāmi al-Alfâz (David b. Abraham al-Fāsī), $873 \mathrm{f}$.
Japanese Graded Readings in Transcription, $901-4$.

Job story, 485-7.

†JoHnston (E. H.), Some Sanskrit Inseriptions of Arakan, 357-385.

Jones (Sir William), his revision of text of two poems of Anacreon, 669-672 ; "New Light" on him, 673-685; in English literature, 686-694; student of Arabic, 695-8; his "Orient Pearls at Random Strung ", 699-712; his influence upon Sanskrit studies, 798-806 ; as jurist, 807817; Jones and The Club, 818-822; as sinologue, 842 .

\section{K}

$k$ - initial in Dravidian, $122-139$.

Kakati (Banikanta, Assamese: its Formation and Development, $889 \mathrm{f}$.

Karaits of Eastern Asia, The (I), M. Dunlop), 276-289.

Kar-fish, tale of the, 482-5.

kārpa $\delta, 470$.

Kawān, 54, 56 ff.

l.ha, 765-7.

Khäqāni, 550-578.

Khāqānī and Andronicus Comnenus (V. Minorsky), 550-578.

Kharosthi Documents, Some Notes on CentralAsian (F. W. Thomas), 513-549.

Khazar, $1 \mathrm{f}$.

Khimi Grammar and Vocabulary (R. Shafer), $386-434$.

Khorāsān, Western, 758-761.

Khotan, Saka language in, 526-536.

Khotan Dharmapada, The (H. W. Bailey), 488-512.

Kinas Konst under tre Artusenden (O. Sirén), 440-442.

Kitāb Jämi al-Alfāz of David ben Abraham. al-Fāsi, $873 \mathrm{f}$.

Konow (Sten), 513 ff.

kremeru, 781.

Krige (E. Jensen) and (J- J).), The Realm of a Rain-Queen, $664 \mathrm{f}$.

$k s-$, phonetic values and changes of, in Gändhārī, 770-5̃.

Kumarappa (Bharatax), The Hindu Conception of the Deity as culminating in Ràmânuja, $229 \mathrm{f}$.

$\mathrm{L}$

Lachish, Fosse-temple of, 656-9.

LAMONTE (ETIENNE), ed., transl,, and comment., La Somme du Grand Véhicule, $446 \mathrm{f}$.

LatTimore (0.), Mongol Journeys, $661 \mathrm{f}$.

LESLAU (WOLF), Documents Tigrigna, 873-5.

Life and Works of Ibn er Rumî (Rhuvon Guest), $873 \mathrm{f}$.

LU (C. H.) and SIMoN (W.), Chinese Reader and Guide to Conversation, 893, 899; Chinese Sentence Series, 893, 899.

Lu Hsiang-shan (Siu-chi Huang), 893, 895 f.

M

Macartaney (C. A.), On the Greek Sources for the History of the Turks in the Sixth Centzry, 266-275. 
McFanland (G. B.), Thai-English Dictionary, $891 \mathrm{f}$.

mahala, $784 \mathrm{f}$.

Mahàyānasamgraha (Asañga), 446 f.

Maine (Sir Henry), compared with Sir W. Jones, 814-17.

$m a k^{6} a, 793-7$.

Malay Language, Survey of Aids for the Study and Teaching of the (M. W. Senstius), $663 \mathrm{f}$.

Māni and Shāpūr, 14 ff.

Manichæan fasts, 42-51 ; hymns, in translation, 174-219; legend of giants, 52-74.

Marv, empire of, $757 \mathrm{f}$.

Marvazi, on China, the Turks, and India, $232-5$.

Master (Alfred), Indo-Aryan and Dravidian, 297-307; The Influence of Sir William Jones upon Sanskrit Studies, 798-806.

$\dagger$ Matthews (Gordon), rev., $890 \mathrm{f}$.

Materials for the Study of the Ssŭ I Kuan (N. Wild), 617-640.

Meile (PIerRe), Introduction au Tamoul, $890 \mathrm{f}$.

Mende, An Introduction to the Study of (K. H. Crosby), $665 \mathrm{f}$.

Merchant and the Spirit, tale of the, $471 \mathrm{f}$.

Ninor Anthologies, The (Sacred Books of the Buddhists $X I I), 231 \mathrm{f}$.

Minorskx (V.), The Gūrān, 75-103; Khāqānì and Andronicus Comnenus, 550-578 ; Roman and Byzantine Campaigns in Atropatene, 243-265 ; ed., with transl. and commty., Sharaf al-Zamān Tähir Marvazì on China, the Turks, and India, 232-5 ; Vis u Rāmīn, a Parthian Romance, 741-763; rev., 659-662, 875-883.

'mnt, 451-464.

Mo Ni Chiao Hsia Pu Tsan, translated by Tsui Chi, 174-219.

Modern Persian Reader (A. J. Arberry), 883.

Moghadam (Mohamad E.) and Armajani (Y.), Descriptive Catalog of the Garrett Collection of . . Manuscripts, $224 \mathrm{f}$.

Mongol Journeys (0. Lattimore), $661 \mathrm{f}$.

Monkey and the Fox, tale of the, $474 \mathrm{f}$.

Mrohaung, inscription at Shitthaung pagoda in, $359-385$.

\section{$\mathrm{N}$}

$\tilde{n}$ - and $n$ - initial in Dravidian, 603-616.

NADEL (S. F.), A Black Byzantium, $905 \mathrm{f}$.

Naganuma Reader, 901-4.

Naǵaraǵa Khvarnarse, 524.

Nalder (L. F.). rev., $443 \mathrm{f}$.

Nani Vadhagá, $524 \mathrm{f}$.

Narasimhia (A. N.), A Grammar of the Oldest Kanarese Inscriptions, $230 \mathrm{f}$.

Nâtakalaksanaratnakośa (Sägaranandin), $226 \mathrm{f}$.

Sature of Consciousness in Hindu Philosophy (S. K. Saksena), 884-6.

N EUfeld (E.), Ancient Hebrew Marriage Laws, 872-3.

New Diplomacy in the Far East (H. van Straelen), 893, 896.

New Light on Sir William Jones (A. J. Arberry), 673-685.

New Official Chinese-Latin Script, The (W. Simon), 893, 898.
Niedergang Irans nach dem Tode Isma'ils I des Grausamen, Der (H. R. Roemer), 875-8.

Niya, $523 \mathrm{n}$.

Note on an Early Indian Coin (L. D. Barnett), $140-3$.

Note on tuthāyatanāni, $A$ (D. E. Hettiaratchi), 579.

Nupe, kingdom of, $905 \mathrm{f}$.

nyă $n a d \bar{u}, \overline{5}$.

\section{0}

oǵana, 793-5.

Ogias, $54 \mathrm{ff}$.

Old Routes of Western Iran (Sir M. Aurel Stein), 659-661.

ommān, $4 \overline{5} 5 \mathrm{f}$.

O'Neill (Herbert S.), rev., 891 f.

Orgitc (P. A. Lanyon-), Grammar of the Pokau Language, 64l-655.

Orient Pearls at Random Strung (A. J. Arberry), 699-712.

\section{$\mathrm{P}$}

Padma-sundara, Alabarasahi-sringaradarpana, 884, 886 f.

Panjab University Library, Catalogue of the Sanskrit Manuscripts in the, 446.

Panjab University Library, A Descriptive Catalogue of Persian, Crdu, and Arabic Manuscripts in the (S. M. Abdullah), $662 \mathrm{f}$. parampula, 778 .

parmiha, $531 \mathrm{f}$.

puta, patta, $546 \mathrm{ff}$.

Pearl-borer, story of the, 465-9.

Peta-vatthu, 231 f.

phägu, 447.

phaligám, 297-304.

Philippos ("Faylaqūs"), 559, 574.

philology, comparative, Sir W. Jones' attitude towards, 804-6.

Phonology of the Sinhalese Inscriptions up to the End of the Tenth Century A.D. (P. B. F. Wijeratne), 580-594, 823-836.

Phraata, 258-263, 265.

Pillared Hall from a Temple at Madura, A (W. Norman Brown), $227 \mathrm{f}$.

Pinto (V. DE Sola), Sir William Jones and English Literature, 686-694.

piro, pirova, pirovala, 536-9.

Pokau language, grammar of the, 641-655.

Pocket Dictionary (Chinese-English) and Pekingese Syllabary (C. Goodrich), 893, 898.

Powelc (L. F.), Sir William Jones and The Club, 818-822.

Prakrit in Khotan, $526 \mathrm{ff}$.

Princeton University Library, Manuscripts in, $225 \mathrm{f}$.

Pritchard (E. E. Evans-), Italy and the Sanusiya Order in Cyrenaica, 843-853; rev., 906-8.

pronouns with initial $n$ - and $y$ - in Dravidian, $596-601,613$.

prw' $y \delta, 484 \mathrm{f}$.

Pūssan in the Rig-Veda (S. D. Atkins), 226.

\section{Q}

Quarterly of the Department of Antiquities in Palestine, X, 2-4, $220 \mathrm{f}$. 
$r$ of Sanskrit in Sinhalese, $835 \mathrm{f}$.

Rabin (ChaIM), Everyday Hebrew, 435, 437 f.

Rāma text, notes on, 3 f.

Rāmānuja, his conception of the Deity, $229 \mathrm{f}$.

RANDLE (H. N.), An Indo-Aryan Language of South India: Saurāșțra-bhāṣā, 104-121, 310-327.

Realm of a Rain-Queen, The (E. Jensen Krige and J. D. Krige), $664 \mathrm{f}$.

Richardson (H. E.) and Gould (Sir Basm), Tibetan Word Book, Tibetan Syllables, and Tibetan Sentences, $445 \mathrm{f}$.

Rita, proper name, 140, 143.

RoEmer (H. R.), Der Niedergang Irans nach dem Tode Isma'ils I des Grausamen, 875-8.

Roman and Byzantine Campaigns in Atropatene (V. Minorsky), 243-265.

Rosenthal (Franz), Ahmad b. at-Tayyib as-Sarahsi, 435, 437.

Row (Davin Nelson), China Among the Powers, 893, 896-8.

Rita, proper name, 140, 143.

$s-s-s$ in Gāndhārì, 785 f

Saadya Studies, $435 \mathrm{f}$.

Sa'adyah Gaon on the Influence of Music (H. G. Farmer), 435-7.

Sacred Books of the Buddhists, Vol. XII: The Minor Anthologies, $231 \mathrm{f}$.

SäGaRanandIN, Nātakalakṣanaratnakośa, $226 \mathrm{f}$.

Saka language in Khotan, 526-536.

Saksena (S. K.), Noture of Consciousness in Hindu Philosophy, 884-6.

Sandoway, inscription at, 359, 361-3, 383.

Sanskrit manuscripts in the Panjab University Library, Catalogue of, Vol. II, 446.

Sanusiya Order in Cyrenaica, 843-853.

as-Sarahsi (Ahmad b. at-Tayyib), 435, 437.

Sasanians, chronology of the early, 6-51.

Sałivakà, 524 .

sàta, 535.

Sattayā (J. Brough), $308 \mathrm{f}$.

Saurāstura-bhāşā, 104-121, 310-327.

Schaffier (Cladde F. A.), rev., 656-9.

Seljuks in Asia Minor, 880-3.

Senior (Mary), rev., $665 \mathrm{f}$.

Sersstius (M. W.), A Survey of Aids for the Study and Teaching of the Malay Language, $663 \mathrm{f}$.

Shafer (RoberT), Khimi Grammar and Vocabulary, 386-434.

Shan-shan, MSS. from, $526 \mathrm{ff}$.

Shāpūr, son of Ardashïr, chronology of, $7 \mathrm{ff}$.

Sharaf al-Zamän Țähir Marvazì on China, the Turks, and India (ed. with transl. and commty., by V. Minorsky), 232-5.

Shi'ite Creed, A (A. A. A. Fyzee), 221, $223 \mathrm{f}$

Shitthaung pagoda, inscription of, 359-385.

Shiz, fire-temple of, 247-250, 253 n., 254-8, $264 \mathrm{f}$.

Short History of the Chinese People (L. C. Goodrich), 893-5.

silpoǵa, 543 ff.

simäbandha, $4 \mathrm{f}$.
SrMoN (WaLTER), How to Study and Write Chinese Characters, 893, 900; The New Official Chinese-Latin Script, 893, 898; 1200 Chinese Basic Characters, 893, 899 f.

Simon (Walten) and Chao (T. C.), Structure Drill in Chinese, 893, $900 \mathrm{f}$.

SimoN (WALTER) and LU (C. H.), Chinese Reader and Guide to Conversation, 893, 899; Chinese Sentence Series, 893, 899.

Sin, worship of, $459 \mathrm{ff}$.

Sinhalese inscriptions, phonology of, 580-594.

Sir W. Jones' Revision of the Text of Two Poems of Anacreon (J. A. Stewart), 669-672.

Sir William Jones and English Literature (V. de Sola Pinto), 686-694.

Sir William Jones and The Club (L. F. Powell), 818-822.

Sir William Jones as Sinologue (A. D. Waley), 842.

Sir William Jones, the Jurist (S. G. VeseyFitżGerald), 807-817.

Srate (O.), Kinas Konst under tre Artusenden, $440-2$.

SMrTH (SidNeY), An Inscription from the Temple of Sin at Huraidha in the Hadhramawt, 451-464.

Sogdian Tales (W. B. Henning), 465-487.

Sogdian Texts of Paris, The (W. B. Henning), $713-740$.

Some Notes on Central-Asian Kharoșthi Documents (F. W. Thomas), 513-549.

Some Sanskrit Inscriptions of Arakan ( $\uparrow$ E. $H$. Johnston), 357-385.

Somme du Grand Véhicule d'Asaña, La, $446 \mathrm{f}$.

Soviet Caucasus, The (D. Tutaeff), 662.

Spaniyaka, 524.

sphat-, sphatika, 297-304.

Spiritual Authority and Temporal Power in the Indian Theory of Government (A. K. Coomaraswamy), $438 \mathrm{f}$.

Ssŭ I Kuan, 617-640.

Stede (W.), rev., $231 \mathrm{f}$.

STEIN (Sir M. AUREL), Old Routes of Western Iran, 659-661.

Stein Collection, Dated Chinese Manuscripts in the, VI (L. Giles), 148-173.

StrwarT (J. A.), Sir W. Jones' Revision of the Text of Two Poems of Anacreon, 669672.

Straelen (H. van), New Diplomacy in the Far East, 893, 896.

Structure Drill in Chinese (W. Simon and T. C. Chao), 893, $900 \mathrm{f}$.

Student of Arabic, The (A. S. Tritton), 695-8. $s \bar{u} c \bar{\imath}, 535 \mathrm{f}$

sulga, $544 \mathrm{ff}$.

Suliǵa Vaǵiti Vadhaǵà, $524 \mathrm{f}$.

SuMmers (G. M.), rev., $889 \mathrm{f}$.

Survey of Aids for the Study and Teaching of the Malay Language (M. W. Senstius), $663 \mathrm{f}$. Swahili, foreign sounds in, 854-871.

$\mathbf{T}$

tt- intervocalic, in Gāndhārī, $783 \mathrm{f}$.

$t-\delta-l$ in Gändhārī, $786 \mathrm{f}$.

Tềhir Marvazi, on China, the Turks, and India, 232-5. 
Takht-i Sulaymān, 249-251, 255, 258, 265.

Tallensi, clanship among the, 906-8.

Tangalūshā, 570, $575 \mathrm{f}$.

Taquzadeh (S. H.), The Early Sasanians, 6-51.

Teucros, of Babylon, $575 \mathrm{f}$.

Thai-English Dictionary (G. B. McFarland), $891 \mathrm{f}$.

Thebarmais, $248 \mathrm{ff}$.

Thomas (E. J.), rev., 226 f., 438 f., 884-7.

Thomas (F. W.), Some Notes on CentralAsian Kharosthi Documents, 513-549.

Tibetan Sentences (Sir Basil Gould and H. E. Richardson), $445 \mathrm{f}$

Tibetan Syllables (Sir Basil Gould and H. E. Richardson), $445 \mathrm{f}$.

Tibetan Word Book (Sir Basil Gould and H. E. Richardson), $445 \mathrm{f}$.

Tìnkalūs, $575 \mathrm{f}$.

titthäyatanāni, 579 .

Tiv People, The (R. C. Abraham), 905 f.

tpn', 479 .

Tritson (A. S.), The Student of Arabic, 695-8; rev., 221-4, 435-8, 873-5.

Tsur ChI, transl. of Mo Ni Chiao Hsia Pu Tsan, 174-219.

triksa, 768-770.

Tucker (A. N.), The Eastern Sudanic Languages, $443 \mathrm{f} . ;$ Foreign Sounds in Swahili, 854-871; rev., $664 \mathrm{f}$.

TUFxell (O.), Wellcome-Marston Archæological Expedition to the Near East. Lachish $I I$, 656-9.

Turkish-Khotanese Vocabulary, A (H. W. Bailey), 290-6.

Turks, Marvazi on the, 232-5.

Turks, On the Greek Sources for the History of the Turks in the Sixth Century (C. A. Macartney), 266-275.

TutaefF (D.), The Soviet Caucasus, 662.

tuthāyatanāni, 579.

1200 Chinese Basic Characters (W. Simon), $893,899 \mathrm{f}$.

U

ummanu, $456 \mathrm{ff}$.

\section{V}

vaidūrya, 304-6.

vamti, $\mathbf{5 3 0} \mathrm{ff}$.

Vasanta Vilāsa, 446-8.

Vasmana, $522 \mathrm{f}$.

veluriya, 304-6.

Vera, 258, 260-3.

Vesälī, inscription on bell at, $358 \mathrm{f}$., 382 .

Vesey-FitzGerald (S. G.). See FitzGerald (S. G. Vesey-).

Vijaya, Vijita, etc., dynastic appellation, 519-521.

Vijita-simha, 513, 520 .

vijnaptipatras, 227-9.

Vimāna-vatthu, $231 \mathrm{f}$.

Vis a Rāmin, a Parthian Romance (V. Minorsky), 741-763.

Vocabulary of Common Japanese Words (A. Rose-Innes), 901-4.

Vyas (K. B.), edit. and comm., Vasanla Vilàsa, 446-8.

\section{W}

WaLeY (A. D.), Sir William Jones as Sinologue, 842.

Wellcome-Marston Archzological Research Expedition to the Near East. Lachish II (O. Tufnell, C. H. Inge, L. Harding), 656-9. WiJeratee (P. B. F.), Phonology of the Sinhalese Inscriptions up to the End of the Tenth Century, 580-594, 823-836.

Wild (Norman), Materials for the Study of the Ssǔ I Kuan, 617-640.

WILKINSON (J. V. S.), rev., 439 f., 883, 887-9. Winstedt (Sir RichaRd 0.), rev., $663 \mathrm{f}$.

\section{$\mathbf{Y}$}

$y$ - initial in Dravidian, 595-616.

$y a \chi^{n i}, 469$.

$y s-$, sign $=z, 533 \mathrm{f}$.

Stephen Austin and Sons, Ltd., Printers, Hertford. 


\section{REVIEWS OF BOOKS}

PAGT

Ancient Hobrew Marriage Laws. By E. Neufeld (S. G. Vesey FitzGerald) . $\quad$ • 872

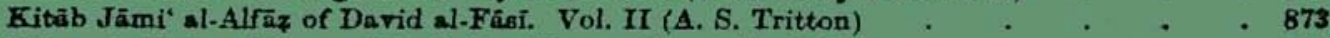

Life and Works of Ibn er Rami. By Rhuvon Guest (A. S. Tritton) . . $\quad$ - $\quad$ - 874

Doouments Tigrigaa. By Wolf Leslau (A. S. Tritton) . . . . . . . . $\quad . \quad 874$

Der Niedergang Irans nach dem Tode Isma'ily I des Grausamen. By H. R. Roemer

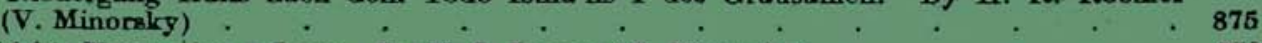

Babidskio Vosstaniya $\nabla$ Irane. By M. S. Ivanov (V. Minorsky) * . . . . $\quad$. 878

Gosudarstro Seldzhukidov Maloi Azii. By V. Gordlevsky (V. Minorsky). . . $\quad$ 879

Modern Persian Reader. By A. J. Arberry (J. V. S. Wilkineon) . . . . $\quad . \quad 883$

Bhagavad Gitā translated and interpreted by Franklin Edgertan (E. J. Thomas) . $\quad 884$

Nature of Conseiousness in Hindu Philosophy. By S. K. Saksena (E. J. Thouas) . $\quad 885$

Akabarasahi-sringaradarpana of Padmasundura (E. J. Thomas) . . . $\quad$. 886

Bulletin of the Baroda State Museum and Picture Gallery. I, 1-2 (J. V. S. Wilkinson) . 887

Civil Service in Indis under the East India Company. By Akshoy Kumar Ghosal (J. V. S. Wilkinson)

Asameso, its Formation and Derelopment. By Banikanta Kakati (G. M. Summers). $\quad 889$

Introduetion au Tamoul. By P. Meile (G. Matthew6). $\quad . \quad$. $\quad . \quad . \quad . \quad$. 890

Thai-English Dictionary. By G. B. McFarland (H.S. O'Xeill) . . . . . $\quad$. 891

A Short History of the Chinese People. By L. C. Gaodrich (L. Giles) . . . $\quad . \quad 893$

Lu Hsiang-shan. By Siu-ehi Huang (L, Giles) . . . . . . . . . . . 896

New Diplomacy in the Far East. By H. $\operatorname{van}$ Straelen (L. Giles) . . . . . . . 898

China Among the Powers. By D. N. Rowe (L. Giles) . . . . . . 896

A Pocket Dictionary (Chinese-English) and Pekingese Syllabary. By C. Goodrich (L. Giles) 898

The New Offlcial Chinese-Latin Seript: Gwoyeu Romatzyh. By W. Bimon (L. Giles) - 898

Chinese Sentence Series. By W. Simon and C. H. Lu (L. Giles) . . . . 899

Chinese Reader and Guide to Conversation. By W. Simon and C. H. Lu (L. Giles).

1,200 Chinese Basic Charaotors. By W. Simon (L. Giles) . . . . . . . 899

How to Study and Write Chinese Characters. By W. Simon (L, Giles) . . . . 000

Structure Drill in Chinese. By W. Simon and T. C. Cheo (I. Giles) . . . .

Japanese Graded Readings in Transcription and Vocabulary of Common Japanese Words
by A. Rose-Innes (F. J. Daniels).

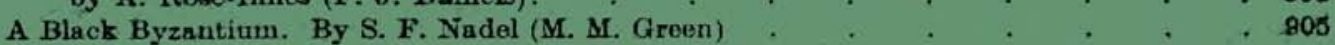

The Tiv People. By R. C. Abraham (M. M. Green) . . . . . . . . . 906

The Dynamice of Clanship among the Tallensi. By M. Fortes (E. E. Evans-Pritchard)

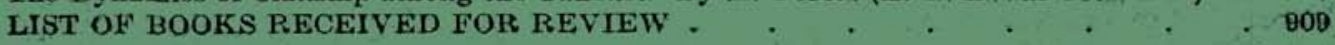

\section{OBITUARY}

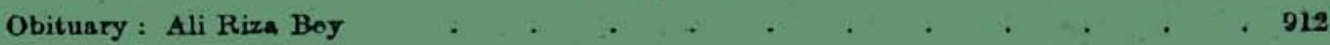

Editor: PROFESSOR R. L. TURNER, Director

All communications to be addressed to-

The Edrtor oy the BuLtetix,

Sohool of Oriental aNd African Studies Library,

Malet Street,

LoNDoN, W.C. 1. 